\title{
Blended learning: Does it help students in understanding mathematical concepts?
}

\author{
Wahyu Setyaningrum \\ Jurusan Pendidikan Matematika, Universitas Negeri Yogyakarta. \\ Jalan Colombo No. 1, Karangmalang, Yogyakarta 55281, Indonesia. \\ * Corresponding Author. E-mail: wahyu_setyaningrum@uny.ac.id \\ Received: 1 October 2018; Revised: 26 October 2018; Accepted: 31 December 2018
}

\begin{abstract}
The rapid development of technology offers many advantages to the proses of learning in the classroom. This experimental research aimed to investigates the effectiveness of learning mathematics delivered through blended learning. In particular, this study compared the effectiveness of blended learning using Moodle and traditional one in relation to students' conceptual understanding. The data was gathered through written test and interview. This study involved 127 students of grade eight secondary school. The data shows that students who learn in blended learning approach have better conceptual understanding rather than their counterparts. The students claim that they can access learning material and revisit some difficult material in their convenience time. Nevertheless, there are some obstacles faced by students related to maintaining their motivation to learn independently and keeping distraction off to access other website when they learn online.
\end{abstract}

Keywords: blended learning, conceptual understanding

How to Cite: Setyaningrum, W. (2018). Blended learning: Does it help students in understanding mathematical concepts?. Jurnal Riset Pendidikan Matematika, 5(2), 244-253. doi:https://doi.org/10.21831/jrpm.v5i2.21428

Permalink/DOI: https://doi.org/10.21831/jrpm.v5i2.21428

\section{INTRODUCTION}

Disruptive technology has affected many aspects of daily life. Most people use some form of technology on a daily basis such as online transportation, online meeting, online classroom, e-banking, and online shopping or e-commerce. Education is one of the areas disrupted by digital technology (Figure 1). Therefore, in the industrial era 4.0, the classroom instruction should be integrated with technology. Technology based learning is one of the examples of technology utilization in the classroom. Many tools and applications have been developed to support classroom instruction.

According to the Internet Worlds Stats, the number of internet users in Indonesia ranked in the fourth place in Asia after China, India, and Japan. There are 78 million Indonesian people us internet in daily life. However, the survey conducted by Teknopreneur found that most of Indonesian use internet to chat with others, and to access social media instead of to support education.
Executives Who Anticipate Moderate or Massive Digital Disruption in the Next 12 Months, by Industry

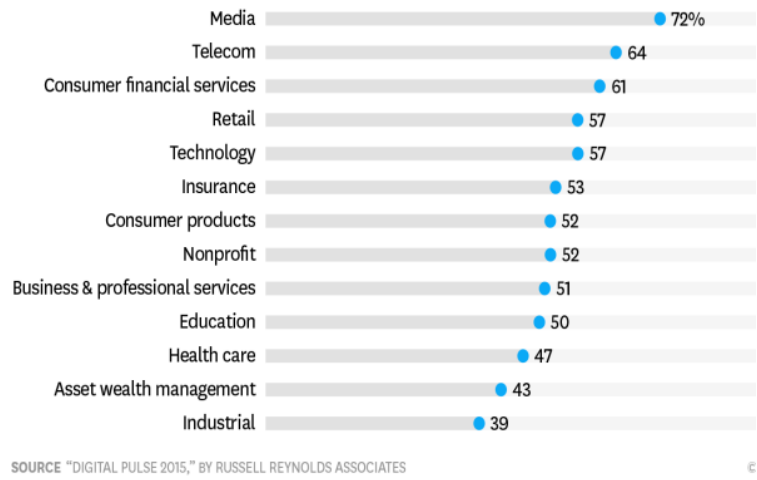

Figure 1. Areas disrupted by digital technology (Grossman, 2016)

Research studies found that technology have huge advantage on education. Technology can be used to develop a learning environment that facilitates higher-order thinking skills (Kurt, 2010). Technology also increases student collaboration (Keser, Huseyin, \& Ozdamli, 2011) and students' achievement, engagement as well as motivation to learn at school (Baytak, Tarman, \& Ayas, 2011). Indeed, technology could offer a 
better educational future with the lower costs to students yet life fulfillment.

In mathematics field, technology can be used as a way to create a hands-on and meaningful mathematics lesson (Herron, 2010) and to visualized mathematical concepts or objects particularly geometrical objects. Students' who spent a lot of time using technology were shown performed better on mathematical skills (Bulut \& Delen, 2011).

Considering the advantage of technology in education, it is necessary to integrate technology into the classroom instruction. Disruptive technology in education could be in form of online learning. Education with this disruption will be more flexible, more formative and more personalized (Gardner, 2016). Some educators, however, argue that online learning could not replace face to face instructions thus face to face interactions are still needed to some extent. The alternative or possible method is blended learning.

This study aimed to investigates the effectiveness of learning mathematics delivered through blended learning in regards to students' conceptual understanding of mathematics. Several studies have been conducted in the field of blended learning and mathematics teaching such as Lin and Chen (2007), Lu and Law (2011), and Lui (2010). They found that blended learning had positive impact on students' cognitive and affective aspects. The impact of blended learning on students' conceptual understanding, however, needs to be investigated especially in developing country as many studies were conducted in develop countries.

Blended learning is the concept that includes framing teaching learning process that incorporates both face to face teaching and teaching supported by ICT. Blended learning incorporates direct instruction, indirect instruction, collaborative teaching, individualized computer assisted learning (Lalima \& Dangwal, 2017:131).

According to Osguthorpe and Graham (2003, p.227), blended learning combines faceto-face with distance delivery systems. In blended learning, the internet is involved, however it is not just simply showing a page from a website on the classroom screen. It involves certain teaching methodologies-pedagogies that change according to the unique needs of learners. Those who use blended learning environments are trying to maximize the benefits of both face-to-face and online methods-using the web for what it does best and using class time for what it does best.

More detail, Dzuiban, Hartman, and Moskal (2004, p. 3) suggests that blended learning should be viewed as a pedagogical approach that combines the effectiveness and socialization opportunities of the classroom with the technological enhancements of the online environment. This implies that blended learning could maximize the advantage of face-to-face and online learning.

There are three elements that one might consider mixing together in a blended course: online and face-to-face learning activities; online and lace-to-face students; and online and face-tolace instructors (Osguthorpe \& Graham, 2003, p. 229). In addition, Cooney, Gupton, and O'Laughlin (2000, p. 168) explain three characteristics of blended learning experiences: blurred lines between play and work; shared control of classroom activities and interactions; and spontaneity present in learning experiences.

In short, blended learning can be define as the integration of classroom face-to-face learning experiences with online learning experiences. However, this is not only mixing the face-to-face and online learning but this should consider the portion of these two aspects as described in Table 1 . Blended learning used in this study composed $30-40 \%$ of online and $60-70 \%$ of face-to-face delivery.

Table 1. Type of Courses

\begin{tabular}{ccl}
\hline $\begin{array}{c}\text { Content } \\
\text { Delivered } \\
\text { Online }\end{array}$ & $\begin{array}{c}\text { Content } \\
\text { Delivered } \\
\text { Face to Face }\end{array}$ & Type of Course \\
\hline $\begin{array}{c}10 \% \\
1 \text { to } 29 \%\end{array}$ & $\begin{array}{c}100 \% \\
\text { to } 99 \%\end{array}$ & $\begin{array}{l}\text { Offline class } \\
\text { Online enhanced } \\
\text { learning }\end{array}$ \\
30 to $79 \%$ & 21 to $70 \%$ & $\begin{array}{l}\text { Blended/Hybrid } \\
\text { learning } \\
\text { Online }\end{array}$ \\
$80+\%$ & 0 to 20\% & (All \\
\hline
\end{tabular}

(Allen \& Seaman, 2006)

Kashefi, Ismail, Yusof, and Rahman (2012, p. 3691) states that blended learning in mathematics should include four aspects as represented in Figure 2. Classroom task: Task that is given in the classroom that also available in the website/online. This task as an insight to support mathematical thinking such as problem solving. Web Aided: Students access material through web such as notes, animation, forum, handout, chat, journal, and other interactive activities as well as feedback. Strategies: Strategies in delivering learning material can be 
web synchronous through online such as chatroom, email, and or discussion board. Teachers also can employ offline strategies such as cooperative learning, inquiry and problem solving. Assessment: In blended learning, teachers can do summative and formative assessments such as quiz, test feedback and written tasks.

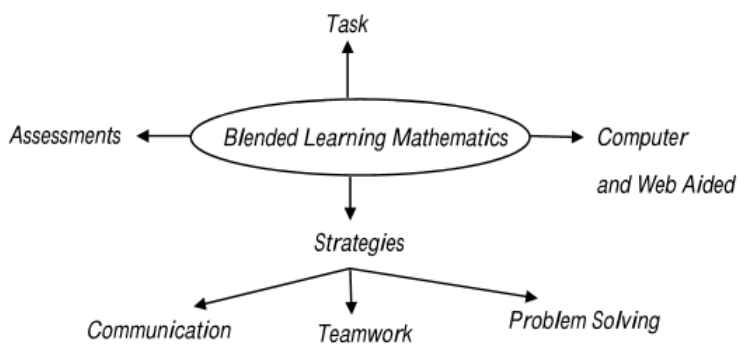

Figure 2. Blended Learning Model (Kashefi, et al., 2012)

Previous research found that blended learning offered several advantages such as: (1) flexible way of learning in terms of time and place, (2) students have autonomous to determine their own learning pace, (3) students have more responsibility on their learning (Tang \& Chaw, 2013). Marco, Penichet, and Lázaro (2013, p. 730) identified main strengths found in blended learning: (1) flexibility because it enables the student to access the materials from anywhere at any time; (2) good student support; (3) improved pedagogy as it supports the face-to-face teaching approaches; (4) increased access and flexibility; (5) increased cost-effectiveness; (6) information from the face-to-face activities to total online interactions is stored in a single place; (7) promotion of social interaction; (8) quick feedback to learners which will help them in their learning process; (9) provides collaborative activities among teacher and students; 10) allows access to everyone who needs training by providing it in different ways.

Blended learning could also promote affective aspect of students, it can increase students' enthusiasm and enjoyment as well as promote independent and self-regulated learning (Tuomainen; 2016), increases student interest, instills a deposition of self-advocacy and provides student autonomy (Hyderali, 2017).

Considering the advantages, it can be concluded that blended learning offers promising learning environment because it provides flexibility in terms of in accessing the material from anywhere at any time, and global resources and materials that meet the students' level of knowledge and interest. Moreover, students can manage their own learning pace either for slow or quick learners so that it could reduce stress, increases satisfaction and information retention.

This study employed Moodle, a free learning management system which is designed for e-learning (http://moodle.org). It has flexible features including the layout, course management, assessment strategy, quizzes, and cooperative learning $(\mathrm{Wu}, 2008)$. The features allow teachers to conduct interactive activities for online group discussion, examinations, and assessments. Moodle enable teachers to enhance teaching materials with text and pictures or graphics and provide clues and evidence to strengthen the students' capacity of comprehension.

Moodle have many advantages for secondary school students as suggested by previous research (Lu, \& Law, 2011; White, 2010). The Moodle was design based on socio-constructivist pedagogy (Shachar \& Neumann, 2010) therefore it allows active and interactive learning to construct students own knowledge.

In regards to the effectiveness of Moodle in mathematics instruction, there has been significant research studies point out that blended learning using Moodle can enhance students' mathematical achievements (Awodeyi, Akpan, \& Udo, 2014; Šumonja, Veličković, \& Šubarević, 2015), help students easily mastering mathematical learning material (Lin, Tseng, \& Chiang, 2017). This learning approach also give positive contribution to students' affective aspect such as students' interest and attitude (MartinBlas \& Serrano-Fernandez, 2009; Somenarain, Akkaraju, \& Gharbaran, 2010; Kotzer, Shulamit, \& Elran, 2012; Zakaria, \& Daud, 2013).

Conceptual understanding can be defined as an integrated and functional grasp of mathematical ideas" (Kilpatrick, Swafford, \& Findell, 2001, p. 118). Marchionda (2006) explains more detail that conceptual mathematics understanding is knowledge that involves a thorough understanding of underlying and foundational concepts behind the mathematics algorithms.

Several researchers use the term conceptual knowledge that is referring to conceptual understanding. Ben-Hur (2006, p. 6) explains that "conceptual knowledge involves understanding concepts and recognizing their applications in various situations. Conversely, procedural knowledge involves the ability to solve problems through the manipulation of mathematical skills .... Obviously, mathematicians invented procedures based on 
mathematical concepts" (Ben-Hur, 2006, p. 6). This implies that conceptual and procedural knowledge are related each other, students with good conceptual understanding could apply the concept by manipulating procedural skills to solve mathematical problems. This is in line with the idea of Kilpatrick, Swafford, and Findell (2001, p. 117), students with conceptual understanding know more than isolated facts and methods ... understand why a mathematical idea is important and the kinds of contexts in which it is useful.

In this study, conceptual understanding in mathematics refers to knowledge of facts and applications of mathematical concepts. This definition can be abstracted that conceptual understanding indicated by: (1) exemplifying the concept; (2) classify the objects into example and non-example; (3) presenting concepts in various forms of mathematical representations; (3) linking the concept with others; and (4) apply the concepts

Many empirical studies revealed that using a blended learning approach improved students' achievement (Awodeyi, Akpan, \& Udo, 2014; Lin et al, 2017). Blended learning facilitates active learning and interactivity between learners as well as diversify the instructional in which students can learn at their own pace. These benefits could help students learn more effectively (Al-Quhtani \& Higgins, 2012; Awodeyi, Akpan, \& Udo, 2014) which could hypothesize that it would increase conceptual understanding.

Research on the application of digital learning platforms and learning achievements has not shown consistent results: some students demonstrated higher performances in learning (Hung, 2007; Liu, 2010; Wang \& Yu, 2012; Wiginton, 2013). While in Indonesian context, this research is still limited. Research on blended learning using mobile application found that students perform better using this learning approach rather than textbook when learning mathematics (Setyaningrum, Pratama \& Ali, 2018). There is a need to explore blended learning using other applications such as learning management system Moodle. So, this research aimed to investigates the effectiveness of learning mathematics delivered through blended learning. In particular, this study compared the effectiveness of blended learning using Moodle and traditional one in relation to students' conceptual understanding

\section{METODE}

This is a quasi-experiment study with the pretest-posttest control and experimental group design as illustrated in Figure 3. Subjects in this study are classify into two groups: experimental group and control group.

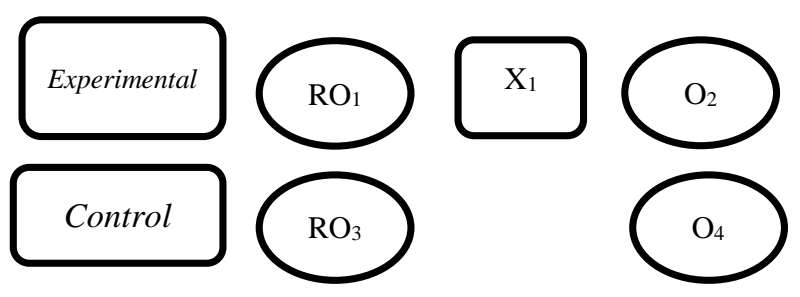

Figure 3. Design of research

\section{Participants}

The participants of this study are students from a public secondary school in Yogyakarta District which is selected using purposive sampling. The school is chosen as it has computer laboratory and internet connection to support blended learning. There are 127 students -88 female and 39 male - of grade 8 aged from 12 to 14 years old $($ Mean $=13.9$; Standart Deviation $=$ 0.5 ). They are placed in four classes namely $8 \mathrm{~A}$, $8 \mathrm{~B}, 8 \mathrm{C}$ and $8 \mathrm{D}$. These classes then randomly assigned into experimental group that is involving students of $8 \mathrm{~A}$ and $8 \mathrm{C}$ and control group that is containing $8 \mathrm{~B}$ and $8 \mathrm{D}$ students.

The school is located in the city of Yogyakarta. Characteristic of subject were student in a school which uses Curriculum 2013 Revision and join Full Day School adjustment. The interval value of students in National Examination was 285.5 up to 303.5 .

\section{Treatment}

In this study, students learn mathematics under one of two conditions: blended learning using Moodle (experimental group) and textbook (control group). The two conditions were identical in terms of: the learning material to be learned that is solid geometry, the lesson structure, the mathematical tasks the students solved, and the number of learning hours at school (6 meeting), each meeting lasted around 80 minutes.

In all four classrooms, students were exposed to the same material with different teaching method blended and conventional. For the experimental group, the blended learning method with Moodle was used as the teaching method. For one and a half months, students in the eight grade took two mathematics courses 
each week in a computer laboratory. In blended learning using Moodle, teachers recorded the teaching materials as videos or looked for Internet resources to be uploaded in Moodle, and to assign to the students for homework before attending each class. Students could also watch the videos whenever they had time at school and or at home. Before each lesson, the students received a set of questions that must be answered before the lesson, and they were asked to prepare one or two questions to ask in class after watching the assigned videos. During the lesson, students were requested to take notes and share their ideas in discussion session. During the discussion, teachers helped and explained issues that students had. In the end of each lesson, online assessment was delivered.

Meanwhile, students in the control group learn mathematics based on conventional teaching method which is the same as teaching method they usually have. In the conventional teaching method, the lesson is divided into three parts: (1) opening and introduction to the learning material (about 10 minutes); (2) teachers explain the material and students working on the problems based on textbook either individually or groups (about 50 minutes); (3) closing: teacher's review of the main ideas of the lesson with the whole class (about 20 minutes). The assessment in the end of each lesson conducted during the closing session.

\section{Instruments}

The main instrument of this study is mathematics test (pre-test and post-test) consisted of 20 multiple choices questions. This instrument aimed to collect data about conceptual understanding of students with and without blended learning instruction. At the end of the experimental instruction, the post-test was administer-ed to all participants in both experimental and control groups to get data of students' conceptual understanding after the treatment.

Validity of instrument for measuring student's mathematics achievement were content validity and quality of validity instrument with discriminant and difficult index of question. A panel of researchers and school teachers who had experience teaching math constructed and reviewed the items to ensure the content validity, clarity, and appropriateness of the instrument to the students' grade level. The test was piloted to 30 students at grade $8^{\text {th }}$ in different school. The reliability referred to a consistence of test to measure student's mathematics achievement.
Test's reliability was measured using Cronbach's Alpha with minimal value of 0.65 . In this study, reliability of instrument both pre-test and posttest were 0,731 and 0,784 respectively (Table 2 ) which are considered as high reliability.

Table 2. Reliability of Instrument Test

\begin{tabular}{lcc}
\hline \multicolumn{1}{c}{ Variable } & $\begin{array}{c}\text { Reliability } \\
\text { coefficient of } \\
\text { Pretest }\end{array}$ & Posttest \\
\hline $\begin{array}{l}\text { Understanding } \\
\text { Mathematical Concepts }\end{array}$ & 0,731 & 0,784 \\
\hline
\end{tabular}

The other instrument to gather data used in this study is interview protocol. Students who taught using blended learning method were interviewed to investigate their perception on the use of Moodle for their learning. It also seeks information about their preference whether they like blended learning or conventional methods usually used by their teachers.

\section{Data Analysis}

The data of students conceptual understanding were analyzed using descriptive analysis and inferential analysis. Descriptive analysis was aimed to give brief comparison on the results of pre-test and post-test between students who given blended learning and conventional teaching method in regards to their conceptual understanding level. The data presented consist of average, standard deviation, achievement of maximum and minimum values. The inferential analysis of variance (ANOVA) was performed to determine the effect of blended learning on students' conceptual understanding.

The data from interview was analyzed using thematic analysis which is including six steps: data transcription, data familiarization, data coding, themes development, reviewing themes and revision. The data familiarization refers to immersing and familiarizing with the content of the interview data by reading and rereading the data. It than followed by coding or labeling that is identify important features of the data that might be relevant to answering the research question. The codes or labels are then examined and re-checked to determine that they resounding the data. The interview data was aimed to portray students' perception and preference in relation to the use of Moodle in mathematics class. 


\section{RESULTS AND DISCUSSION}

\section{Description of Mathematics Achievement}

Based on conceptual understanding test about solid geometry in experiment class and control class, the result shows that students taught through blended learning have better conceptual understanding than those who taught with conventional method. This can be seen from average score by taking into account the standard deviation. Data description of conceptual understanding is summarized in Table 3.

The data above, however, does not provide enough information to conclude that blended learning affect students' conceptual understanding. Therefore, the ANOVA test is needed to get this information.

Table 3. Description of conceptual understanding

\begin{tabular}{lcccc}
\hline \multirow{2}{*}{ Description } & \multicolumn{4}{c}{ Result of research } \\
\cline { 2 - 5 } & \multicolumn{2}{c}{ Experiment } & \multicolumn{2}{c}{ Control } \\
\cline { 2 - 5 } & Pre-test & Post-test & Pre-test & Post-test \\
\hline Sum of student & 63 & 63 & 64 & 64 \\
Sum of score & 2210 & 5358 & 2307 & 5071 \\
Mean & 35,08 & 85,05 & 36,05 & 79,23 \\
$\begin{array}{l}\text { Standard } \\
\text { Deviation }\end{array}$ & 10,45 & 11,24 & 12,61 & 14,05 \\
$\begin{array}{l}\text { Maximum } \\
\text { Score } \\
\quad \text { Minimum }\end{array}$ & 40 & 100 & 35 & 100 \\
Score & 10 & 60 & 10 & 50 \\
\hline
\end{tabular}

\section{Inferential Data Analysis}

A two-way Analysis of Variance (ANOVA) was performed to determine the effect of blended learning on students' conceptual understanding. Tabel 4 presents the mean scores, standard deviation and estimated effect size in both condition. Regarding the pretest, there was no significant differences between the two treatments on prior knowledge $(\mathrm{F}(1,109)=2.48$, $p>0.05)$. These results showed that the initial conditions of both groups for prior knowledge are the same. The main effect of the tratment was significant $(\mathrm{F}(1,87)=4.77, p<0.05)$ for the posttest data. These results was due to a larger difference (12.26) between blended learning method and conventional method under the posttest. As can be seen from Tabel 4, students who studied with blended learning method had a higher mean score than those who taught in conventional method. This implies that blended learning method affected students' conceptual understanding.
Table 4. Estimated effect sizes experiment and control groups

\begin{tabular}{lccc}
\hline Group & $\begin{array}{c}\text { Pretest } \\
\text { Mean (SD) }\end{array}$ & $\begin{array}{c}\text { Posttest } \\
\text { Mean (SD) }\end{array}$ & $\begin{array}{c}\text { Effect } \\
\text { Size }\end{array}$ \\
\hline Control & 36.05 & 79.23 & 0.91 \\
& $(12.61)$ & $(14.05)$ & \\
Experimental & 35.08 & 85.05 & 1.23 \\
& $(10.45)$ & $(11.24)$ & \\
\hline
\end{tabular}

In regards to students' perception on the implementation of blended learning in mathematics lesson, most of the students in the experimental group have positive perception on blended learning. More than half of students (72\%) claim that they can learn mathematics in more convenience way as they can explore material using video and internet at home rather than reading textbook. This means they prefer to use blended learning in mathematics lessons. The students' reasons of are summarized in Figure 4.

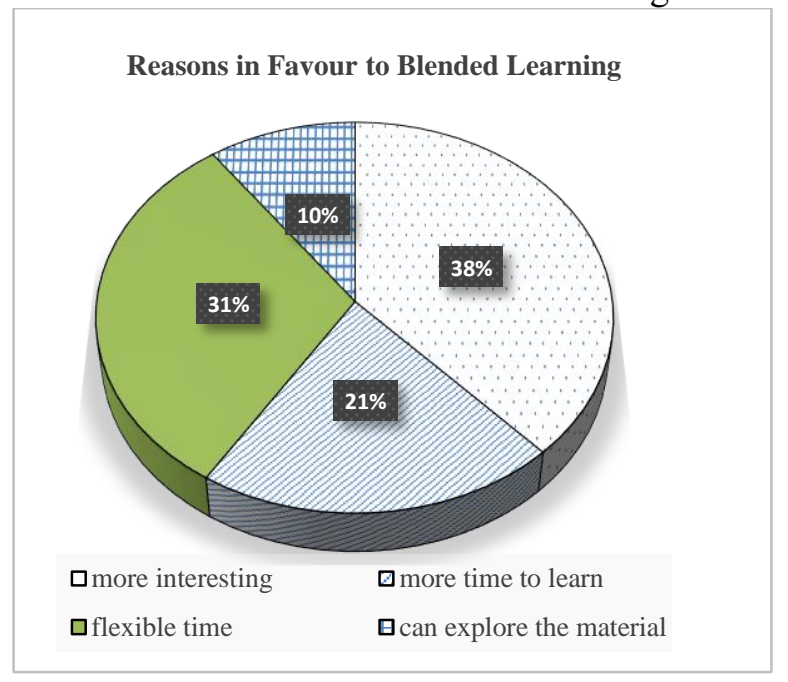

Figure 4. Percentage of the reasons of students who like blended learning

Meanwhile, the rest of the student states that blended learning is an interesting method of teaching that can be used as an alternative method of teaching. Nevertheless, they encountered several problems during online phase of blended learning such as internet connection, difficulties in understanding learning material, and difficulties in managing concentration. Thus, they prefer to non-blended learning method.

When students in experimental group were asked whether blended learning could help them learn mathematical concepts, most of them agreed that blended learning helped them in certain way. The use of video helped students the most as they prefer to watch video about the mathematical concepts rather than read textbook. Others claimed that online learning was more 
interesting than reading printed book. In addition, they stated that online learning using Moodle provide immediate feedback of their works. If their work incorrect, they could see the correct answers from the feedback.

\section{Discussion}

The results provided in the previous section show that, students who were taught in blended learning significantly outperformed their counterparts who were taught in conventional teaching method. As discussed earlier, many studies have indicated the blended learning is more effective in terms of academic achievement than traditional method (Hung, 2007; Liu, 2011; Wang \& Yu, 2012; Wiginton, 2013). In this study, blended learning is better than conventional teaching methods in terms of improving students' conceptual understanding in mathematics lesson. The reason of this may be related to the flexibility provided in blended learning. If each student has their own access to learning material, they can control their learning pace and re-read any material they encounter any problems. This was not happened in conventional method, if students missed some information, it is difficult for them to catch up on what they have missed.

In the online phase of blended learning, students can browse learning materials as much as they need and repeat exercises to understand the learning material. Within these processes, students actively used learning resources, rather than passively accepting information or learning material from teachers. This can enhance student learning of mathematical concepts (Lin, et al., 2017). This is in line with interview results that reveal $21 \%$ of the students in experiment group like blended learning because they have more time to learn by repeating the materials as well as the exercises.

Furthermore, online assessment and immediate feedback can help to improve conceptual understanding. Students who receive immediate feedback perform better than those who had delayed feedback or those who did not receive any feedback (Brosvic, Epstein, Cook, \& Dihoff, 2005). In blended learning, student get homework in Moodle therefore this could be another aspect that support students' learning as explained by Mendicino, Razzaq, and Heffernana (2009) that students learned effectively using web-based homework with immediate feedback than using the paper-based homework. The interview data support this claim, students in favor with the use of blended learning as it provides immediate feedback so that they can learn from the feedback especially when they have incorrect answers.

Blended learning, therefore, could considered as one of the alternatives to improve students' conceptual understanding in mathematics class. Nevertheless, there are some students have some problems when using blended learning as identified in the interview. The first issue is internet connection, this implies that teachers need to examine and make sure that students have sufficient internet connection before applying this approach so that it will bring advantages to the students. In regard to the second issue that is difficulties in understanding learning material, this can be minimalized by discussing difficult material in face-to-face phase. The last issue is difficulties in managing concentration. The students state that they keep opening the social media while learning online, it is hard to hold back maintain focus in Moodle. This issue would be one of the hardest problems since this is related to personal willingness or personal selfregulated learning. The teachers, however, could give motivation and courage that might help students to focus on learning rather than opening other application.

\section{CONCLUSION}

This study intended to investigate the effect of blended learning on students' conceptual understanding. The data shows that students who exposed to blended learning have better conceptual understanding than the students who exposed to conventional teaching method. The interview reveal that the students have positive perception on blended learning even tough they face some problems during implementation of blended learning. Based on the results of this study, it can be suggested that blended learning using Moodle should be widely used to enhance students' active learning and to construct knowledge so that it can improve students understanding of mathematical concepts. Students' access to the internet, however, should be considered before implementing this teaching method. Another issue is related to the generalization, as the sample was limited to one school with middle-class students, any generalizations drawn from the findings of this study should be considered with caution.

\section{DAFTAR PUSTAKA}

Allen, I. E., \& Seaman, J. (2006). Making the
grade: Online education in the United 


\section{Jurnal Riset Pendidikan Matematika, 5 (2), 2018 - 251}

Wahyu Setyaningrum

States, 2006. Needham, MA: The Sloan Consortium.

Al-Qahtani, A. A., \& Higgins, S. E. (2013). Effects of traditional, blended and elearning on students' achievement in higher education. Journal of Computer Assisted Learning, 29(3), 220-234. doi:10.1111/j.1365-2729.2012.00490.x.

Awodeyi, A. F., Akpan, E. T., \& Udo, I. J. (2014). Enhancing teaching and learning of mathematics: adoption of blended learning pedagogy in University of Uyo. International Journal of Science and Research, 3(11), 40-45.

Baytak, A., Tarman, B., \& Ayas, C. (2011). Experiencing technology integration in education: children's perceptions. International Electronic Journal of Elementary Education, 3(2), 139-151.

Ben-Hur, M. (2006). Concept-Rich Mathematics Instruction. Alexandria, VA: ASCD.

Brosvic, G., Epstein, M., Cook, M., \& Dihoff, R. (2005). Efficacy of error for the correction of initially incorrect assumptions and of feedback for the affirmation of correct responding: Learning in the classroom. The Psychological Record, 55, 401-418.

Bulut, O., \& Delen, E. (2011). The relationship between students' exposure to technology and their achievement in science and math. The Turkish Online Journal of Educational Technology, 10(3), 311-317.

Chang, R., \& Yang, C. (2016). Developing a mobile app for game-based learning in middle school mathematics course. 2016 International Conference on Applied System Innovation (ICASI), 1-2.

Cooney, M. H., Gupton, P., \& O'Laughlin, M. (2000). Blurring the lines of play and work to create blended classroom learning experiences. Early Childhood Education Journal, 27(3), 165-171.

Dzuiban, C., Hartman, J., \& Moskal, P. (2004). Blended learning. Educause Center for Applied Research, Research Bulletin, 7. Retrieved from http://net.educause.edu/ir/library/pdf/ERB 0407.pdf.

Grossman, R. (2016). The industries that are being disrupted the most by digital.
Retrieved from https://hbr.org/2016/03/the-industriesthat-are-being-disrupted-the-most-bydigital

Herron, J. (2010). Implementation of technology in an elementary mathematics lesson: The experiences of pre-service teachers at one university. SRATE Journal, 19(1),22-29.

Hung, C. H. (2007). The effectiveness of an interactive website in teaching a common factors and multiples course at the elementary level (Unpublished master's thesis). National Yunlin University of Science and Technology, Yunlin, Taiwan.

Hyderali, R. (2017). An insight into the advantages and disadvantages of blended learning. Contemporary Research in India, 7(2), 317-320.

Kashefi, H., Ismail, Z., Yusof, Y. M., \& Rahman, R. A. (2012). Supporting students mathematical thinking in the learning of two-variable functions through blended learning. Procedia:Social and Behavioral Science, 46, 3689-3695.

Keser, H., Uzunboylu, H., \& Ozdamli, F. (2012). The trends in technology supported collaborative learning studies in $21^{\text {st }}$ century. World Journal on Educational Technology, 3(2), 103-119.

Kilpatrick, J., Swafford, J., \& Findell, B. (2001). Adding It Up Helping Children Learn Mathematics. Washington, DC: National Academy Press.

Kotzer, S., \& Elran, Y. (2012). Learning and teaching with Moodle-based E-learning environments, combining learning skills and content in the fields of Math and Science \& Technology. In Proceeding of 1st Moodle Research Conference (pp. 122131). Crete-Greece: Heraklion.

Kurt, S. (2010). Technology use in elementary education in Turkey: A case study. New Horizons in Education, 58(1), 65-76.

Lalima, L., \& Dangwal, K. L. (2017). Blended learning: An innovative approach. Universal Journal of Educational Research, 5, 129-136. doi:10.13189/ujer.2017.050116.

Lin, H. W., \& Chen, L. C. (2007). The effects of using Moodle online learning on the sixth- 
grade science course. In S. M. Chang (Eds.), Proceedings of the 2007 Conference/Research \& Development in Technology Education (pp. 23-30). Kaohsiung, Taiwan: National Kaohsiung Normal University.

Lin, Y. W., Tseng, C. L., \& Chiang, P. J. (2017). The effect of blended learning in mathematics course. EURASIA Journal of Mathematics Science and Technology Education, 13(3), 741-770.

Liu, F. C. (2010). An effectiveness of Moodle eLearning services designed for geometry learning in elementary school (Unpublished master's thesis). Asia University, Taichung, Taiwan.

Lu, J., \& Law, N. W. Y. (2011). Understanding collaborative learning behavior from Moodle $\log$ data. Interactive Learning Environments, 20(5), 451-466.

Marchionda, H. (2006). Preservice teacher procedural and conceptual understanding of fractions and the effects of inquiry-based learning on this understanding. (Unpublished Doctoral Dissertation). Clemson University, South Carolina.

Marco, F. A., Penichet, V. M. R., \& Lázaro, J. A. G. (2013). Drawer: An innovative teaching method for blended learning. In S. F. Tang, \& L. Logonnathan (Eds.), Taylor's $7^{\text {th }}$ teaching and learning conference proceedings (pp. 727-734). Singapore: Springer.

Martín-Blas, T., \& Serrano-Fernández, A. (2009). The role of new technologies in the learning process: Moodle as a teaching tool in Physics. Computers \& Education, 52(1), $35-44$.

Mendicino, M., Razzaq, L., \& Heffernana, N. (2009). A comparison of traditional homework to computer-supported homework. Journal of Research on Technology in Education, 41(3), 331-358.

Osguthorpe, R. T., \& Graham, C. R. (2003). Blended learning systems: Definitions and directions. Quarterly Review of Distance Education, 4(3), 227-234.

Setyaningrum, W., Pratama, L. D., \& Ali, M. B. (2018). Game-based learning in problem solving method: The effects on students' achievement. International Journal on
Emerging Mathematics Education, 2(2), 157-164. doi:10.12928/ijeme.v2i2.10564

Shachar, M., \& Neumann, Y. (2010). Twenty years of research on the academic performance differences between traditional and distance learning: Summative meta-analysis and trend examination. Journal of Online Learning and Teaching, 6(2), 318-334.

Somenarain, L., Akkaraju, S., \& Gharbaran, R. (2010). Student perceptions and learning outcomes in asynchronous and synchronous online learning environments in a Biology course. Journal of Online Learning and Teaching, 6(2), 353-356.

Šumonja, S., Veličković, V., \& Šubarević, T. (2015). Applying ICT in the teaching of mathematics in high school. IMVI Open Mathematical Education Notes, 5(1), 3146.

Tang, C. M., \& Chaw, L. Y. (2016). Digital literacy: A prerequisite for effective learning in a blended learning environment? The Electronic Journal of eLearning, 14(1), 54-65.

Tuomainen, S. (2016). A blended learning approach to academic writing and presentation skills. International Journal on Language, Literature and Culture in Education, 3(2). doi:10.1515/llce-20160009.

Wang, Y. Z., \& Yu, C. Z. (2012). A study of influence on learning motivation and effectiveness with the Moodle learning platform in mathematics area's remedial instruction-example of grade 3 . In C. F. Wang (Eds.), Proceedings of the 2012 Symposium on Digital Content and Virtual Learning Conference. Pingtung, Taiwan: National Pingtung University.

White, B. (2010). Using ICT to enhance curriculum opportunities for students in rural and remote schools. Australian Educational Computing, 25(2), 27-30.

Wiginton, B. L. (2013). Flipped instruction: An investigation into the effect of learning environment on student self-efficacy, learning style, and academic achievement in an algebra I classroom. (Unpublished doctoral dissertation). University of Alabama, Tuscaloosa. 
Jurnal Riset Pendidikan Matematika, 5 (2), 2018 - 253

Wahyu Setyaningrum

Wu, W. S. (2008). The application of Moodle on an EFL collegiate writing environment. Journal of Education and Foreign Languages and Literature, 7, 45-56.
Zakaria, E., \& Daud, M. Y. (2013). The role of technology: Moodle as a teaching tool in a graduate mathematics education course. Asian Journal of Management Science \& Education, 2(4), 46-52. 